\title{
Smoking-Attributable Mortality in Cuba
}

\section{Patricia Varona Pérez, Delia Herrera Travieso, René Guillermo García Roche, Mariano Bonet Gorbea, Teresa Romero Pérez, Silvia Josefina Venero Fernández}

Translated from the Spanish and reprinted with permission from the Revista Cubana de Salud Pública (Rev Cubana Salud Pública v.35 n.2, April-June, 2009, http://bvs.sld.cu/revistas/spu/vol35_2_09/spu15209.htm)

\begin{abstract}
Introduction Smoking is the main preventable cause of death worldwide. The World Health Organization estimates that smoking causes 5 million deaths annually, a figure that could double shortly if the present trend in tobacco product consumption continues.
\end{abstract}

Objectives Estimate smoking-attributable mortality in the Cuban population and provide information needed to carry out effective public health actions.

Methods This is a descriptive study using smoking prevalence and mortality data in Cuba for 1995 and 2007. Causes of death were grouped in three categories: malignant tumors, cardiovascular diseases and chronic respiratory diseases. Etiological fractions and attributable mortality were calculated by cause and sex.

\section{INTRODUCTION}

The present and future effects of smoking on health are the chief reason for the explicit, sustained and steadfast support behind the worldwide anti-smoking drive.[1]

Smoking is the main cause of preventable death in the world. Tobacco is the only legal consumer product that kills between one-third and one-half of its consumers.[2-5]

According to WHO reports, smoking causes an estimated 5 million deaths annually.[6,7]

Several recent studies using different methods have attempted to assess the impact of smoking on mortality. Ischemic heart disease, chronic obstructive respiratory disease, and tracheabronchus-lung tumors are the major causes of death from smoking.[8-10] The two former causes account for over half of mortality due to smoking and for over $80 \%$ if malignant tumors are added.[11-13]

According to global statistics, taken together, these noncommunicable diseases have been the primary causes of death worldwide for more than 20 years, representing more than $75 \%$ of annual deaths and constituting the primary causes of early mortality in Years of Potential Life Lost (YPLL) and of disability in DisabilityAdjusted Life Years (DALYs).[14-15]

In Cuba, heart diseases have been the primary cause of death for the last 35 years. According to 2007 statistics, the rate was 187.3 $\times 10^{5}$, followed by malignant tumors $\left(181.2 \times 10^{5}\right)$, cerebrovascular diseases $\left(75.4 \times 10^{5}\right)$ and chronic obstructive lower respiratory tract diseases $\left(28.2 \times 10^{5}\right)$, all causally associated with smoking.[16]

Although the National Surveys on Risk Factors and Chronic Diseases and other research have provided data on tobacco use and
Results Of deaths recorded in 1995 and $2007,15 \%$ and $18 \%$ of preventable deaths were attributed to smoking, respectively. In Cuba in 2007, smoking caused $86 \%$ of deaths from lung cancer, $78 \%$ of deaths from chronic obstructive pulmonary disease, $28 \%$ of deaths from ischemic heart disease, and $26 \%$ of deaths from cerebrovascular disease.

Conclusions Smoking is responsible for high rates of preventable mortality in Cuba. There is willingness on the part of administrative and political authorities to discourage smoking, and more than half of smokers in Cuba wish to quit smoking. Given awareness that reducing smoking is the most effective means of decreasing preventable morbidity and mortality, the country is moving steadily toward concrete, sustainable steps leading to increased life expectancy and quality of life for the Cuban population.

Keywords: Smoking, preventable mortality, preventable morbidity, Cuba

its characteristics, no recent population-wide epidemiological studies have been conducted to determine the impact of smoking on mortality in Cuba. Estimating mortality attributable to the use of tobacco products is one of the most important steps in developing guidelines for concrete action plans aimed at prevention and control of this addiction. The purpose of this study is to provide health and governmental authorities with information needed to carry out effective, comprehensive, coordinated public health actions.

\section{METHODS}

This is a descriptive study on mortality associated with smoking in the Cuban population. Prevalence data for smokers, former smokers and non-smokers, overall and by sex, were obtained from the National Surveys on Risk Factors and Chronic Diseases, conducted in all urban areas of the country in 1995 and during the period from November 2000 to March 2001. Results of these surveys were representative of the national population and the population by province. A complex sampling design (stratified and multi-stage clustering) was used, based on the general sampling design created in 1995 by the National Statistics Bureau for the household survey system and updated in 1999.[17,18]

Individuals were categorized as smoker (smoked at least one cigarette or cigar daily at the time of the survey and for a minimum of one month prior), former smoker (not smoking at the time of the survey but had smoked regularly before), and non-smoker (not smoking when the survey took place and never smoked). Mortality data for 1995 and 2007-chosen because national prevalence information was available for proximate years-was obtained from Cuban Health Statistical Yearbooks. Information in the Yearbooks has been evaluated by the Pan American Health Organization as quite reliable and consistent.[16,19,20]

Variables included were age (for cardiovascular disease, given availability of information on relative risk of death in 
different subgroups) and sex, according to the $9^{\text {th }}$ and $10^{\text {th }}$ editions of the International Classification of Diseases (ICD-9 and 10).[21,22]

Causes of death that have an established association with smoking were distributed into three groups:

Group I: malignant tumors (lung-trachea-bronchus, lip-oral cavity-throat, esophagus, larynx, cervix, bladder and urinary tract, kidney and pancreas).

Group II: cardiovascular diseases (ischemic heart disease and cerebrovascular disease in groups aged $35-64$ years and $>64$ years).

Group III: respiratory diseases (chronic bronchitis and emphysema).

The source for relative risk used for both smokers and former smokers was a prospective epidemiological cohort study carried out between 1982 and 1988 by the American Cancer Society: Cancer Prevention Study II (ACS CPS-II),[23] which may be a limitation of the present study, since data were not obtained directly from the Cuban population (Table 1).

Table 1: Estimated Relative Risk Associated with Smoking for Smokers and Former Smokers, by Sex and Cause of Death[23]

\begin{tabular}{|c|c|c|c|c|}
\hline \multirow[t]{2}{*}{ Cause of Death } & \multicolumn{2}{|c|}{$\mathbf{R R}^{*}$ (Men) } & \multicolumn{2}{|c|}{ RR* (Women) } \\
\hline & Smokers & $\begin{array}{l}\text { Former } \\
\text { smokers }\end{array}$ & Smokers & $\begin{array}{l}\text { Former } \\
\text { smokers }\end{array}$ \\
\hline \multicolumn{5}{|c|}{ Neoplasms } \\
\hline Trachea-bronchus-lung & 22.3 & 9.3 & 11.9 & 4.6 \\
\hline Lip-oral cavity-throat & 27.4 & 8.8 & 5.5 & 2.8 \\
\hline Esophagus & 7.6 & 5.8 & 10.2 & 3.1 \\
\hline Larynx & 10.4 & 5.2 & 17.7 & 11.8 \\
\hline Cervix & - & - & 2.1 & 1.9 \\
\hline Bladder and urinary tract & 2.8 & 1.9 & 2.5 & 1.8 \\
\hline Kidney & 2.95 & 1.95 & 1.4 & 1.1 \\
\hline Pancreas & 2.14 & 1.12 & 2.3 & 1.7 \\
\hline \multicolumn{5}{|c|}{ Cardiovascular diseases } \\
\hline \multicolumn{5}{|l|}{ Ischemic heart disease: } \\
\hline $35-64$ years & 2.8 & 1.8 & 3.0 & 1.4 \\
\hline$>64$ years & 1.6 & 1.3 & 1.6 & 1.3 \\
\hline \multicolumn{5}{|l|}{ Cerebrovascular disease: } \\
\hline $35-64$ years & 3.7 & 1.4 & 4.8 & 1.4 \\
\hline$>64$ years & 1.9 & 1.3 & 1.4 & 1.0 \\
\hline \multicolumn{5}{|c|}{ Respiratory diseases } \\
\hline $\begin{array}{l}\text { Chronic bronchitis and } \\
\text { emphysema (COPD) }\end{array}$ & 9.6 & 8.7 & 10.4 & 7.0 \\
\hline
\end{tabular}

*Relative risk compared to persons who never smoked.

The smoking-attributable fraction was calculated for each disease by sex for 1995 and 2007 (Table 2).

Once the attributable fractions, population proportional attributable risk (PPAR) and absolute mortality for each condition were established, smoking-attributable mortality (SAM) was calculated for each of the selected causes using an indirect method based on prevalence analysis, which considers relative risk for smokers and former smokers compared to non-smokers, by sex, as well as prevalence of these conditions. The following equations were used:

PPAR $=1-1 /\left[P_{0}+P_{1}\left(R R_{1}\right)+P_{2}\left(R R_{2}\right)\right]$
Table 2: Population Etiologic Fractions (\%) for Men and Women by Cause of Death, 1995 and 2007

\begin{tabular}{|c|c|c|c|c|}
\hline \multirow[t]{2}{*}{ Cause of Death } & \multicolumn{2}{|c|}{ Men } & \multicolumn{2}{|c|}{ Women } \\
\hline & 1995 & 2007 & 1995 & 2007 \\
\hline \multicolumn{5}{|c|}{ Neoplasms } \\
\hline Trachea-bronchus-lung & 96 & 92 & 87 & 75 \\
\hline Lip-oral cavity-throat & 94 & 93 & 78 & 54 \\
\hline Esophagus & 79 & 77 & 83 & 69 \\
\hline Larynx & 84 & 82 & 94 & 83 \\
\hline Cervix & - & - & 65 & 26 \\
\hline Bladder and urinary tract & 50 & 45 & 36 & 31 \\
\hline Kidney & 50 & 49 & 50 & 10 \\
\hline Pancreas & 35 & 32 & 63 & 28 \\
\hline \multicolumn{5}{|c|}{ Cardiovascular disease } \\
\hline Ischemic heart disease: & & & & \\
\hline $\begin{array}{r}35-64 \text { years } \\
>64 \text { years }\end{array}$ & $\begin{array}{l}48 \\
24\end{array}$ & $\begin{array}{l}46 \\
35\end{array}$ & $\begin{array}{l}36 \\
14\end{array}$ & $\begin{array}{l}34 \\
14\end{array}$ \\
\hline \multicolumn{5}{|l|}{ Cerebrovascular disease: } \\
\hline $35-64$ years & 55 & 54 & 51 & 48 \\
\hline$>64$ years & 32 & 30 & 9 & 10 \\
\hline \multicolumn{5}{|c|}{ Respiratory disease } \\
\hline $\begin{array}{l}\text { Chronic bronchitis and } \\
\text { emphysema (COPD) }\end{array}$ & 84 & 83 & 89 & 73 \\
\hline
\end{tabular}

where: $P_{0}, P_{1}$ and $P_{2}$ are prevalence in non-smokers, smokers and former smokers, respectively, and $R R_{1}$ and $R R_{2}$ represent relative risks for smokers and former smokers compared to nonsmokers. [24]

SAM = PPAR $x$ number of deaths in the groups studied.

\section{RESULTS}

Of total deaths recorded in Cuba in 1995 (77,932) and 2007 $(81,922), 11,951$ and 15,083 deaths were attributed to smoking in the three groups of selected causes, representing $15 \%$ and $18 \%$ of all deaths, respectively; $67 \%$ (1995) and $69 \%$ (2007) of these smoking-attributable deaths were among males. Smoking accounted for $19 \%$ and $24 \%$ of deaths in men, and $11 \%$ and $12 \%$ of women in 1995 and 2007, respectively.

In 1995 and 2007, smoking in Cuba caused, respectively, 93\% (96\% in men and $87 \%$ in women) and $86 \%$ (92\% in men and $75 \%$ in women) of deaths from trachea-bronchus-lung cancer; $86 \%$ ( $84 \%$ in men and $88 \%$ in women) and $78 \%$ (83\% in men and $73 \%$ in women) of deaths from chronic obstructive pulmonary disease (COPD); $24 \%$ (29\% in men and $17 \%$ in women) and $28 \%$ (38\% in men and $17 \%$ in women) of deaths from ischemic heart disease; and $27 \%$ (37\% in men and $17 \%$ in women) and $26 \%$ (34\% in men and $16 \%$ in women) of deaths from cerebrovascular disease. Cardiovascular diseases and cancer were the most frequent causes of death attributed to smoking in 1995 (52\% and 40\%, respectively) and in 2007 (42\% each). Among total deaths attributed to smoking, deaths due to COPD increased from $8 \%$ in 1995 to $16 \%$ in 2007.

Group I causes of death: The attributable fractions for both men and women in 1995 and for men in 2007 fluctuated between $32 \%$ and $96 \%$. In women, in 2007 , these ranged between $10 \%$ and $83 \%$, as shown in Table 2. These etiologic fractions decreased between the two periods.

In 2007, lip-oral cavity-throat cancer had the greatest attributable fraction among men, followed by trachea-bronchus-lung cancer; 
in women, cancer of the larynx had the largest fraction followed also by trachea-bronchus-lung cancer.

The latter site accounted for the greatest etiologic fraction in men and occupied second place in women in 1995, the year in which the greatest difference in fractions between sexes was observed in pancreatic cancer, followed by oral cavity-throat and bladderurinary tract cancers. By 2007, trachea-bronchus-lung cancer occupied second place in both sexes, as shown in Table 2.

It is noteworthy that while mortality from trachea-bronchus-lung cancer in men increased by 33.5\% from 1995 to 2007, this increase was $61.2 \%$ in women (Tables 3 and 4 ).

Table 3: Overall Mortality and Smoking-Attributable Mortality in Men by Cause of Death, 1995 and 2007

\begin{tabular}{|c|c|c|c|c|}
\hline \multirow[t]{2}{*}{ Cause of Death* } & \multicolumn{2}{|c|}{1995} & \multicolumn{2}{|c|}{2007} \\
\hline & OD & $\overline{A D}$ & OD & $\overline{A D}$ \\
\hline \multicolumn{5}{|c|}{ Neoplasms } \\
\hline Trachea-bronchus-lung & 2,300 & 2,208 & 3,207 & 2,950 \\
\hline Lip-oral cavity-throat & 340 & 319 & 425 & 395 \\
\hline Esophagus & 304 & 240 & 465 & 358 \\
\hline Larynx & 405 & 340 & 657 & 539 \\
\hline Cervix & - & - & - & - \\
\hline Bladder and urinary tract & 267 & 133 & 335 & 150 \\
\hline Kidney & 85 & 42 & 128 & 63 \\
\hline Pancreas & 260 & 91 & 388 & 124 \\
\hline Subtotal & 3,961 & 3,373 & 5,605 & 4,579 \\
\hline \multicolumn{5}{|c|}{ Cardiovascular disease } \\
\hline $\begin{array}{r}\text { Ischemic heart disease: } \\
35-64 \text { years } \\
>64 \text { years }\end{array}$ & $\begin{array}{l}2,156 \\
7,625\end{array}$ & $\begin{array}{l}1,034 \\
1,830\end{array}$ & $\begin{array}{l}2,009 \\
6,035\end{array}$ & $\begin{array}{r}924 \\
2,112\end{array}$ \\
\hline $\begin{array}{r}\text { Cerebrovascular disease: } \\
35-64 \text { years } \\
>64 \text { years }\end{array}$ & $\begin{array}{r}794 \\
2,913\end{array}$ & $\begin{array}{l}436 \\
932\end{array}$ & $\begin{array}{r}840 \\
3,267\end{array}$ & $\begin{array}{l}453 \\
980\end{array}$ \\
\hline Subtotal & 13,488 & 4,232 & 12,151 & 4,469 \\
\hline \multicolumn{5}{|c|}{ Respiratory disease } \\
\hline $\begin{array}{l}\text { Chronic bronchitis and } \\
\text { emphysema (COPD) }\end{array}$ & 544 & 456 & 1,681 & 1,395 \\
\hline Total & 17,993 & 8,061 & 19,437 & 10,443 \\
\hline
\end{tabular}

Attributable deaths accounted for $32 \%-33 \%$ of total deaths from cancer in both sexes in Cuba during the two periods analyzed; 8 of every 10 deaths among men in the selected sites were attributed to smoking, and these in turn accounted for $40 \%$ of total male cancer deaths (8,482 in 1995 and 11,586 in 2007). In women, 6 of every 10 death from cancer in the sites shown in Table 4 were attributable to smoking, accounting for $20 \%-22 \%$ of female cancer deaths $(6,124$ in 1995 and 8,774 in 2007).

Smoking-attributable cancer accounted for $6 \%$ of overall mortality in the country in 1995 and $8 \%$ in 2007.

Seven of every 10 deaths from smoking-associated cancer occurred in men, and $64 \%$ of these were from trachea-bronchuslung cancer. In women, $69 \%$ of attributable deaths were in this same site, which was the main cause of death from smoking, leading to 750 deaths in 1995 and 1,209 deaths in 2007. Mortality from cancer attributable to tobacco use was 2.4 and 2.6 times higher in men than in women in 1995 and 2007, respectively.
Table 4: Overall Mortality and Smoking-Attributable Mortality in Women by Cause of Death, 1995 and 2007

\begin{tabular}{|c|c|c|c|c|}
\hline Cause of Death* & \multicolumn{2}{|c|}{1995} & \multicolumn{2}{|c|}{2007} \\
\hline & OD & AD & OD & AD \\
\hline \multicolumn{5}{|c|}{ Neoplasms } \\
\hline Trachea-bronchus-lung & 863 & 750 & 1,612 & 1,209 \\
\hline Lip-oral cavity-throat & 91 & 71 & 154 & 83 \\
\hline Esophagus & 85 & 70 & 134 & 92 \\
\hline Larynx & 74 & 69 & 97 & 80 \\
\hline Cervix & 335 & 217 & 465 & 120 \\
\hline Bladder and urinary tract & 110 & 40 & 148 & 46 \\
\hline Kidney & 50 & 30 & 90 & 9 \\
\hline Pancreas & 245 & 154 & 357 & 100 \\
\hline Subtotal & 1,853 & 1,401 & 3,057 & 1,739 \\
\hline \multicolumn{5}{|c|}{ Cardiovascular disease } \\
\hline $\begin{array}{r}\text { Ischemic heart disease: } \\
35-64 \text { years } \\
>64 \text { years }\end{array}$ & $\begin{array}{l}1,152 \\
6,787\end{array}$ & $\begin{array}{l}415 \\
950\end{array}$ & $\begin{array}{r}997 \\
6,123\end{array}$ & $\begin{array}{l}339 \\
857\end{array}$ \\
\hline $\begin{array}{r}\text { Cerebrovascular disease: } \\
35-64 \text { years } \\
>64 \text { years }\end{array}$ & $\begin{array}{r}763 \\
3,203\end{array}$ & $\begin{array}{l}389 \\
288\end{array}$ & $\begin{array}{r}619 \\
3,267\end{array}$ & $\begin{array}{l}297 \\
326\end{array}$ \\
\hline Subtotal & 11,905 & 2,042 & 11,006 & 1,819 \\
\hline \multicolumn{5}{|c|}{ Respiratory disease } \\
\hline $\begin{array}{l}\text { Chronic bronchitis and } \\
\text { emphysema (COPD) }\end{array}$ & 503 & 447 & 1,483 & 1,082 \\
\hline Total & 14,261 & 3,890 & 15,546 & 4,640 \\
\hline
\end{tabular}

*ICD-10

OD: Observed deaths

AD: Attributable deaths

Group II causes of death: The etiologic fractions calculated for ischemic heart disease and cerebrovascular disease were greater for men than women, and greater for the group aged 35-64 years in both sexes and in both years studied (1995 and 2007), as shown in Table 2.

Smoking was associated with 3 of every 10 deaths from isquemic heart disease among men aged $\geq 35$ years in $1995(12,085$ deaths), and with 4 of every 10 deaths in the same group in 2007 $(11,042$ deaths); among women in the same age group, this fraction was 2 of every 10 deaths from the same cause in both years $(9,961$ and 10,006 deaths, respectively).

In Cuba, in 1995 and 2007, for every death from smokingattributable ischemic heart disease and cerebrovascular disease among both men and women aged 35-64 years, there were 2 deaths from the same causes in the group aged $>64$ years. Deaths from cardiovascular disease accounted for $8 \%$ of overall mortality in the country during both years studied. Attributable mortality among men was 2.3 times higher than among women.

Group III causes of death: Estimated attributable fractions put this cause among the three primary causes of death linked to smoking.

Eight of every 10 deaths from chronic bronchitis and emphysema in men in both years were attributable to smoking; in women, however smoking was associated with 9 of every 10 deaths in 1995, dropping to 7 of every 10 in 2007.

Deaths due to smoking represented $1 \%$ and $3 \%$ of total deaths from these causes in 1995 and 2007, respectively. In 2007, the 
attributable mortality in men (1,395 deaths) was $29 \%$ higher than in women (1,082 deaths).

\section{DISCUSSION}

Tobacco use is responsible for high mortality in Cuba.

The decrease in etiologic fractions between 1995 and 2007 observed in Group I can be explained by a reduction in the prevalence of smokers along with an increase in the number of former smokers of both sexes.

Based on data collected in this study, it is estimated that 2 people die every hour in Cuba from smoking-attributable causes, a figure possibly underestimated in 2007 , since only diseases most frequently associated with tobacco use were included in the analysis. Even so, it exceeds the proportion of smoking-attributable mortality in the adult population worldwide $(12 \%)$ and that reported in countries such as Canada (16.6\%), Paraguay (13.4\%) and France (12\%). Rates in the United States and Mexico have been estimated at $24 \%$ and $27 \%$, respectively.[25-27]

A major reduction in smoking could have prevented 15,083 deaths in Cuba in 2007: 6,318 from cancer, 6,288 from cardiovascular disease and 2,477 from chronic bronchitis and emphysema, all leading causes of death in the adult Cuban population.

Such a reduction should be possible, given the commitment of administrative and political authorities and the willingness of more than half of smokers to try to quit. A study by Varona Pérez et al. of factors associated with stages of behavior change in the Cuban smoker population showed that 6 of every 10 smokers wanted to quit smoking, which places Cuba in a favorable situation for developing anti-smoking interventions.

This is reinforced by the fact that most of the identified factors associated with behavior change (age of initiation to the addiction, cigarette consumption and attempts to quit, and environments that actively discourage smoking) are modifiable.[28]

Recent genetic and epidemiological research have demonstrated the function of family aggregation and genetic factors in smoking, including initiation to the addiction, quitting, and nicotine dependence, documented in twin and population studies; yet, the contribution of environmental factors from the initiation stage through 'quitting for good' is the strongest element determining both active and passive smoking behavior.[29]

In general, enough is known globally about what to do to achieve effective smoking prevention and control, and Cuba, in particular, has the necessary information on the scope and characteristics of this addiction in its population.

Reducing smoking has been established as the most effective way to lower preventable morbidity and mortality, and the country is moving steadily toward the adoption of sustainable actions aimed at increasing Cubans' life expectancy at birth and quality of life.

\section{REFERENCES}

1. Aveyard P, West R. Managing smoking cessation. BMJ. 2007;335:37-41

2. Organización Mundial de la Salud. Iniciativa librarse del tabaco. Juventud libre de tabaco Informe de un Grupo Científico de la OMS; 2008 Ginebra: OMS [Internet]. [updated 2008, cited 2008]. Available from: http://www.who.int/tobacco/wntd/2008/es/

3. Banegas Banegas JR, Díez-Gañán L. Epidemiología del Tabaquismo. Morbi-mortalidad. In: Jiménez Ruiz CA, Fagerström KO, editors. Tratado de Tabaquismo. Madrid: Grupo Aula Médica S.L.;2004. p.11-27.

4. Vila Roig B, Adell Aparicio C, Bell Panisello C, Tolosa Martínez N, Brau Beltrán J. Características de fumadores que acuden a una consulta de deshabituación tabáquica (2001-2003). Prev Tab. 2003;5(supl 1):51.

5. Dorado Morales G, Varela Martínez I de J, Cepero Guedes A, Barreiro Alberdi O. Hábito de fumar y alcoholismo en un consultorio médico. Rev Cubana Enfermer [serial on the Internet]. 2003 [cited 15 Oct 2008 ];19(2). Available from: http://scielo sld.cu/scielo.php?script=sci_arttext\&pid=S086403192003000200004\&lng=es\&nrm=iso

6. Achiong Estupiñán $F$, Morales Rigau JM, Dueñas Herrera A, Acebo Figueroa F, Bermúdez González C, Garrote Rodríguez I. Prevalencia y riesgo atribuible al tabaquismo. Rev Cubana Hig Epidemiol [serial on the Internet]. 2006 [cited 5 Oct 2008];44(1). Available from: http://www.bvs. sld.cu/revistas/hie/vol44 1 06/hie01106.htm

7. Organización Panamericana de la Salud. La Salud en Las Américas. Washington: OPS. 2002. 587(1):197-8. Publicación Científica y Técnica.

8. Doll R, Peto R, Boreham J, Sutherland I. Mortality in relation to smoking: 50 years' observations on male British doctors. BMJ. 2004;328:1519.

9. Bustamante Navarro R, Lobregad Espuch C, Hidalgo Quiles MJ, Schwarz Chavarri H, De la Cruz Amorós $\mathrm{E}$. Características de los fumadores que acuden a una unidad de tabaquismo en régimen ambulatorio. Prev Tab. 2005;7(1):11-6.

10. Díez-Gañán L, Banegas JR. Morbilidad y mortalidad derivadas del consumo de tabaco. Especial referencia a España. Prev Tab. 2005;7(1):17-30.

11. Kuri-Morales P, Alegre-Díaz J, Mata-Miranda MP, Hernández-Ávila M. Mortalidad atribuible al consumo de tabaco en México. Salud Pública Mex. 2002;44(supl 1):S29-S33.

12. Samet JM. Los riesgos del tabaquismo activo y pasivo. Salud Pública Mex. 2002;44 (supl 1):S144-S160.

13. San Martín V, Gamarra de Cáceres G. Mortalidad atribuible al consumo de tabaco, años 1998 , 1999 y 2000 en Paraguay. Mem Inst Inves Ciencias Salud. 2006;4(1) Revista Cubana de Salud Pública. 2009; 35(2) http://scielo.sld.cu 12

14. Organización Panamericana de la Salud. Tendencias del consumo de tabaco en el mundo. En: La epidemia del tabaquismo, los gobiernos y los aspectos económicos del control del tabaco. Publicación Científica $N^{\circ} 577$. Washington, D.C: Organización Panamericana de la Salud, 2000; 15-21.

15. Martínez-Gutiérrez María Soledad, Vanegas L Jairo, Reveco U Sandra, Valenzuela R Rodrigo, Arteaga H Oscar. Estudio piloto: costos directos atribuibles al tabaquismo en dos hospitales de Santiago. Rev. Méd. Chile [serial on the Internet]. 2008 Oct [cited 2009 Jun 26]; 136(10): 1281-1287. Available from: http://www.scielo.cl/scielo.php?script=sci_arttext\&pid=S003498872008001000007\&lng=es
16. Ministerio de Salud Pública de Cuba. Situación de Salud en Cuba. Indicadores Básicos 2007 Dirección Nacional de Registros Médicos y Estadístico. Ministerio de Salud Pública de Cuba. La Habana: MINSAP;2008.

17. Barroso Utra I, Cañizares Pérez M, Lera Márques L. Influencia de la estructura de los datos en la selección de los métodos de análisis estadísticos. Rev Esp Salud Pública. 2002;76(2):3.

18. Cañizares Pérez M, Barroso Utra I, Alfonso León A, García Roche R, Alfonso Sagué K, Chang de la Rosa $\mathrm{M}$, et al. Estimaciones usadas en diseños muestrales complejos: aplicaciones de la encuesta de salud cubana del año 2001. Rev Panam Salud Pública. 2004;15(3):176-84.

19. Ministerio de Salud Pública de Cuba. Anuario Estadístico de Salud. Havana: MINSAP;1995.

20. Organización Panamericana de la Salud. Informe Estrategia para el Fortalecimiento de las Estadísticas Vitales y de Salud de los países de las Américas. Cuba: Situación de las estadísticas vitales y de salud. Washington: OPS;2007.

21. International Organization Health. ICD-9a. International Statistical Classification of Diseases and related Health problems. Geneva: WHO;1992.

22. International Organization Health. ICD-10a. International Statistical Classification of Diseases and related Health problems [data base on the Internet]. [updated 25 Aug 2006; cited 2006]. Available from: http://www.who.int/classifications/icd/icd10updates/en/index.html

23. Centers for Disease Control and Prevention (CDC). U.S. Department of Health and Human Services. Reducing the Health consequences of smoking. 25 Years of Progress. A report of the Surgeon General. Atlanta: CDC;1989. 
24. Pérez-Ríos M, Montes A. Methodologies used to estimate tobacco-attributable mortality: a review. BMC Public Health [serial on the Internet]. 2008 Jan [cited 22 Jan 2008];8(22). Available from: http://www.biomedcentral.com/1471-2458/8/22

25. Rehm J, Baliunas D, Brochu S, Fisher B. The costs of substance abuse in Canadá 2002. [monograph on the Internet]. 2006 [updated 2006, cited Mar 2006]. Available from: http://www.google.es/ search?hl=es_q=Rehm+J.\%2CBaliunas+D.\%2C + Brochu+S._btnG=Buscar+con +Google_meta=

26. Centers for Disease Control and Prevention (CDC). Cigarette smoking among adultsUnited States, 1998. Morb Mortal Wkly Rep. 2000;49:881-4.

27. Tapia-Conyer R, Kuri-Morales $\mathrm{P}$, Hoy-Gutiérrez MJ. Panorama epidemiológico del tabaquismo en México. Salud Publica Mex. 2001;43(5):478-84.

28. Varona P. Factores asociados a etapas de cambio de comportamiento en fuma- dores cubanos. Rev Panam Salud Pública. 2003;14(2):119-24

29. Broms U. Nicotine Dependence and Smoking Behaviour. A Genetic and Epidemiological Study. BMJ [serial on the Internet]. 2008 Oct [cited 6 Oct 2008]. Available from: http://scholar.google.es/scholar?hl=es $\mid r=$ $q=$ related:uNzBHgbQu6EJ:scholar.google. com/_um=1_ie=UTF-8_sa=X_oi=science_links_ resnum $=1$ ct $=$ sl-related

\section{THE AUTHORS}

Patricia Varona Pérez, (Corresponding author: patricia.varona@infomed.sld.cu, patricia. varona@inhem.sld.cu), associate researcher, National Institute of Hygiene, Epidemiology and Microbiology, Havana, Cuba.
Delia Herrera Travieso, research intern, National Institute of Hygiene, Epidemiology and Microbiology, Havana, Cuba.

René Guillermo García Roche, associate researcher, National Institute of Hygiene, Epidemiology and Microbiology, Havana, Cuba.

Mariano Bonet Gorbea, epidemiologist, National Institute of Hygiene, Epidemiology and Microbiology, Havana, Cuba.

Teresa Romero Pérez, full professor, National Cancer Control Unit. Havana, Cuba.

Silvia Josefina Venero Fernández, adjunct researcher, National Institute of Hygiene, Epidemiology and Microbiology, Havana, Cuba.

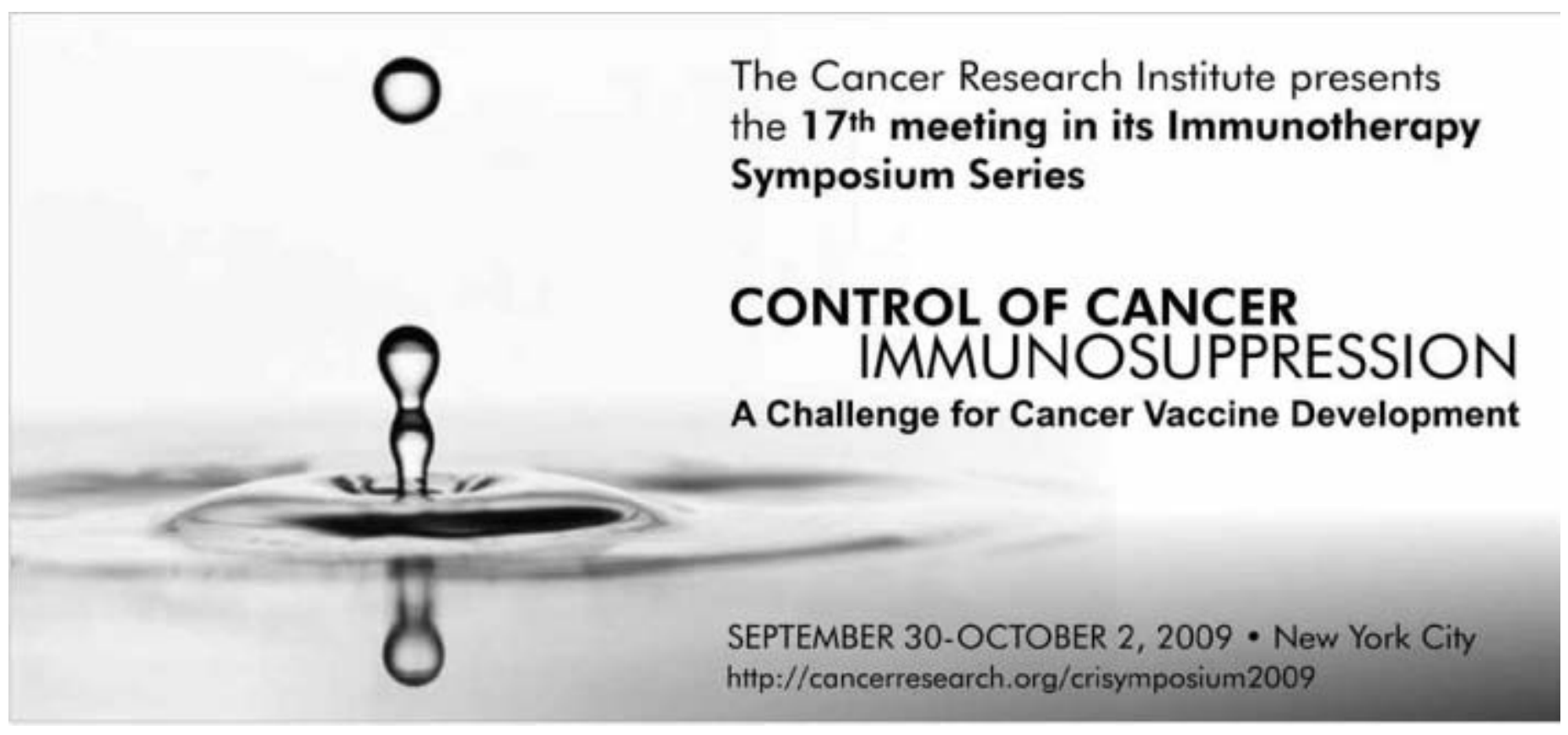

